\title{
Groundwater Contamination Caused by Road Construction Materials
}

\author{
R. Ličbinský*, J. Huzlík, I. Provalilová, V. Jandová \\ Transport Research Centre, Division of transport infrastructure and environment, Brno, Czech Republic \\ * Corresponding author: roman.licbinsky@cdv.cz
}

\section{Ličbinská}

$V \check{S} B$ - Technical University of Ostrava, Faculty of Mining and Geology, Institute of geological engineering, Ostrava, Czech Republic

DOI: $10.2478 / \mathrm{v} 10158-012-0023-2$

\begin{abstract}
Materials used for the construction of roads can represent one of the sources of environmental pollution. In this respect, especially the water migrating in the road body can be contaminated by pollutants released from these materials. This paper presents the results of a study focused on the leaching of compounds from materials used for road construction. At localities with older pavement surfaces, concentrations of polyaromatic hydrocarbons (PAHs) detected in samples from different body layers were highest in the layer subjacent to the asphalt pavement surface and decreased in the direction to underlying layers. The highest concentrations of PAHs were found in the pavement surface at the locality with the newest pavement surface. Toxicity tests showed adverse effects on test organisms at all localities in the first layer, i.e. the asphalt pavement surface, as well as in the third or fourth layer. On the contrary, samples with the highest concentrations of PAHs were classified as non-toxic, with zero mortality of test organisms. In samples of infiltration water the same PAHs as in soils were identified, with the highest concentrations detected for pyrene, benzo(a)pyrene, and fluoranthene. Water filtration through the road bodies can be classified as slightly toxic to test organisms.
\end{abstract}

KEY WORDS: water; road; PAH; metals; leaching.

\section{INTRODUCTION}

Alternative materials have been used for the construction of road pavements between the $60 \mathrm{~s}$ and $80 \mathrm{~s}$ of the last century. At that time it was crucial to meet the technical requirements for construction, but these materials could have a negative impact on some components of the environment. Particularly the water migrating on the road body, carried away by drainage systems, may be contaminated by pollutants released from these materials. A number of organic and inorganic pollutants were identified in the water leaving a road body (Krein \& Schorer, 2000; Legret \& Pagotto, 1999; Stotz \& Krauth, 1994) that may accumulate in the vicinity of roads and can thus lead to significant pollution of the environment (Legret et al., 1996). Potential pollutant occurrence in water in road bodies can originate from bitumen leaching as organic material derived from petroleum containing different types of hydrocarbons and from the content of many chemicals generated from road traffic during the use of the pavement, including vehicle exhausts, gasoline, lubricating oils, tires and brake lining wear (Legret et al., 2005). The major chemicals typically investigated in relation 
to asphalt pavement are heavy metals like $\mathrm{Cd}, \mathrm{Cr}, \mathrm{Cu}, \mathrm{Ni}, \mathrm{Pb}$ and $\mathrm{Zn}$ and polycyclic aromatic hydrocarbons (PAHs) (Lindgren, 1996; Brantley \& Townsend, 1999, Legret et al., 2005). Legret et al. (2005) described leaching of selected heavy metals and polyaromatic hydrocarbons (PAHs) from samples containing $10 \%$ and $20 \%$ of reclaimed asphalt pavement surface. Leaching of PAHs from samples of commonly used commercial bituminous mixtures and asphalts at low concentrations was also documented by other studies (Brandt \& de Grooth 2001; Pagotto et al., 2000). Pollution of surface water and groundwater by selected risk elements from pavements that were constructed with the use of crushed ash is considered insignificant, except for potassium $(\mathrm{K})$, sodium $(\mathrm{Na})$ and sulphates that were detected in high concentrations and may originate from this material (Arnold et al., 2002). The leachability of selected pollutants from various agglutinated and non-agglutinated materials - both conventional and alternative - used for the construction of road bases - is significantly dependent on the $\mathrm{pH}$ of the environment (Hill et al., 2001). The pavement surface layer may also be a source of pollution of surface water that if not captured and specifically drained can infiltrate into the soil and rock environment in the vicinity of roads. This infiltration inevitably leads to pollution of verges. However, this pollution remains localised in the top layer of soil, where as much as $90 \%$ of pollutants remain effectively captured (Berbee et al., 2004). However, pollutants bound on colloidal particles that may pass even through filter devices in settling tanks are an issue (Sansalone \& Buchberger, 1995). Runoff water from road surfaces is more contaminated by emissions from motor vehicles than water infiltrating through porous asphalt into the road body from where it is drained (Legret et al., 1996).

\section{METHODOLOGICAL PROCEDURES}

Boreholes were drilled at three localities with a different age of the pavement; at all localities samples were taken of individual structural layers and at one locality a seeping waters sampler was installed. The core drilling method was applied to drill the boreholes, using a mobile drilling rig and a drill bit with an inside diameter of $25 \mathrm{~cm}$. The borehole was drilled step by step, with each step of approximately $30 \mathrm{~cm}$, and the particular core section was put at a pre-prepared stacking place. The borehole depth was measured on reaching the subgrade. From each layer of the road body profile, approximately $500 \mathrm{~g}$ of soil were collected in a polyethylene sample container for the determination of inorganic substances, and $500 \mathrm{~g}$ in a glass sample container for the determination of organic substances and toxicity tests.

To determine the concentrations of inorganic substances in particular layers, samples were dried, homogenized and transferred to a solution by dissolving them in a mixture of acids. Subsequently, analyses were conducted on devices ICP - OES (iCAP 6500, Thermo Scientific, USA) and FAAS (AA 280 FS, VARIAN, Australia). Prior to the determination of concentrations of organic substances, samples were transferred to hexane, using supercritical fluid extraction (Lizard 2000, Seko-K s.r.o., Czech Republic). Subsequently, the extract was purified with the use of column chromatography on a silica gel sorbent. The eluates obtained were then preconcentrated to the required volume and the determination of selected organic pollutants contents was carried out using GS-MS (QP 2010, Shimadzu, Japan).

Water extracts from soil samples were also prepared, according to the methodology defined by the standard ČSN EN 12457-4 (2002). After 24 hour shaking (KS 130 basic, IKA, Germany) the extract was centrifuged at $3900 \mathrm{~g}$ for 10 minutes (Universal 32, Hettlich, Germany), filtered if necessary (coarse material) and its $\mathrm{pH}$ was determined. The water extract was tested to assess the possible effects on living organisms with a commercially produced test Thamnotoxkit FTM (SOP, Thamnotoxkit F, 1995), using Thamnocephalus platyurus as a test organism. 
A seeping waters sampler was installed into the borehole at locality 1 to describe the pollution of the environment by substances released from material used for road construction. After completion of the borehole and having taken the samples, the device was put on the borehole bottom. Then the borehole was carefully filled with corresponding layers of soil in the exact order in which the layers had been uncovered by drilling. The scheme and location of the sampler within the pavement, the device's main parts, and the principles of operation are described in detail in Leitão et al. (2008).

\section{RESULTS AND DISCUSSION}

\subsection{Road layers}

The individual layers found in the borehole drilled in the road on a particular locality were described macroscopically and a profile through the road - the sequence of layers - was made (Figure 1). Separate layer characteristics are summarized in table 1. Layers were described in accordance with specific standards ČSN EN 13108-1 (2008), ČSN EN 13108-5 (2008) and ČSN 736133 (2010). Tag AC 20; $50 \mathrm{~mm}$ means a surface course made of Asphalt Concrete with aggregates of $20 \mathrm{~mm}$ in diameter and a $50 \mathrm{~mm}$ thickness of the layer.

Table 1: Summary of separate layers characteristics.

\begin{tabular}{|c|c|c|c|}
\hline $\begin{array}{l}\text { Layer } \\
\text { No. }\end{array}$ & Locality 1 & Locality 2 & Locality 3 \\
\hline 1 & $\begin{array}{l}\text { surface layer - AC 20;50 } \\
\text { mm. }\end{array}$ & $\begin{array}{l}\text { surface layer - AC 20; } 70 \\
\text { mm. }\end{array}$ & $\begin{array}{l}\text { surface layer - AC 12, } 250 \\
\text { mm. }\end{array}$ \\
\hline 2 & $\begin{array}{l}\text { G-C - gravel mixed with } \\
\text { clay soil - } \\
\text { brown-gray colour, gravel } \\
\text { component (max. } 40 \mathrm{~mm} \text { ) } \\
\text { of deep igneous and } \\
\text { metamorphic rocks with } \\
\text { irregular shapes } \\
\text { thickness } 200 \mathrm{~mm}\end{array}$ & $\begin{array}{l}\text { G-M - gravel mixed with fine } \\
\text { grained soil - } \\
\text { black-gray colour, gravel } \\
\text { component (max. } 30 \mathrm{~mm} \text { ) of } \\
\text { deep igneous and } \\
\text { metamorphic rocks with } \\
\text { irregular shapes, occasionally } \\
\text { slag } \\
\text { thickness } 150 \mathrm{~mm}\end{array}$ & $\begin{array}{l}\text { G-M - gravel mixed with } \\
\text { fine grained soil - } \\
\text { black-gray colour, gravel } \\
\text { component (max. } 50 \mathrm{~mm} \text { ) } \\
\text { of deep igneous and } \\
\text { metamorphic rocks with } \\
\text { irregular shapes, } \\
\text { occasionally slag } \\
\text { thickness } 100 \mathrm{~mm}\end{array}$ \\
\hline 3 & $\begin{array}{l}\mathrm{G} \text { - gravel - } \\
\text { gray-black colour, gravel } \\
\text { and sand component (max } \\
3 \mathrm{~cm} \text { ) of slag and cinder } \\
\text { thickness } 100 \mathrm{~mm}\end{array}$ & $\begin{array}{l}\text { G-M - gravel mixed with fine } \\
\text { grained soil - } \\
\text { brown colour, gravel } \\
\text { component (max. } 30 \mathrm{~mm} \text { ) of } \\
\text { deep igneous and metamorphic } \\
\text { rocks with irregular shapes, } \\
\text { thickness } 150 \mathrm{~mm}\end{array}$ & $\begin{array}{l}S \text { - sand - } \\
\text { yellow - brown colour, } \\
\text { gravel component } \\
\text { (max. } 10 \mathrm{~mm}) \\
\text { thickness } 600 \mathrm{~mm}\end{array}$ \\
\hline 4 & $\begin{array}{l}\text { G-F - gravel mixed with } \\
\text { fine grained soil - } \\
\text { dark brown to gray colour, } \\
\text { gravel component (max. } 50 \\
\text { mm) of deep igneous and } \\
\text { metamorphic rocks with } \\
\text { irregular shapes } \\
\text { thickness } 200 \mathrm{~mm}\end{array}$ & $\begin{array}{l}\text { G-F - gravel mixed with fine } \\
\text { grained soil - } \\
\text { brown - red colour, rock } \\
\text { component (more than } 200 \\
\text { mm) of metamorphic rocks } \\
\text { with irregular shapes } \\
\text { thickness } 400 \mathrm{~mm}\end{array}$ & $\begin{array}{l}\mathrm{S}-\text { sand - } \\
\text { brown colour, gravel } \\
\text { component (max. } 40 \mathrm{~mm} \text { ) } \\
\text { of metamorphic rocks with } \\
\text { irregular shapes } \\
\text { thickness - remains to the } \\
\text { end of the bore hole }\end{array}$ \\
\hline
\end{tabular}




\begin{tabular}{|c|c|c|c|}
\hline $\begin{array}{l}\text { Layer } \\
\text { No. }\end{array}$ & Locality 1 & Locality 2 & Locality 3 \\
\hline 5 & $\begin{array}{l}\text { G-F - gravel mixed with } \\
\text { fine grained soil - } \\
\text { dark brown to gray colour, } \\
\text { stony component (max } 10 \\
\mathrm{~cm} \text { ) of deep igneous and } \\
\text { metamorphic rocks with } \\
\text { irregular shapes } \\
\text { thickness } 35 \mathrm{~cm}\end{array}$ & $\begin{array}{l}\mathrm{S} \text { - sand - } \\
\text { gray - black colour, sand } \\
\text { component }(\mathrm{max} 2 \mathrm{~mm}) \\
\text { thickness } 200 \mathrm{~mm},\end{array}$ & \\
\hline 6 & $\begin{array}{l}\mathrm{F} \text { - fine grained soil - } \\
\text { brown - gray colour, gravel } \\
\text { component }(\max 40 \mathrm{~mm}) \\
\text { thickness } 150 \mathrm{~mm}\end{array}$ & $\begin{array}{l}\text { F - fine grained soil - } \\
\text { gray - brown colour, } \\
\text { thickness - remains to the end } \\
\text { of the bore hole }\end{array}$ & \\
\hline 7 & $\begin{array}{l}\mathrm{S}-\mathrm{C} \text { sand mixed with clay } \\
\text { soil - } \\
\text { brown colour, } \\
\text { thickness - remains to the } \\
\text { end of the bore hole }\end{array}$ & & \\
\hline
\end{tabular}

Concentrations of EPA's 16 priority pollutant polyaromatic hydrocarbons (PAHs) including coronene were determined in samples taken from individual layers of the road body. The obtained results indicate that concentrations of substances decrease with increasing depth, which is well evident from graphs in Figure 2, where concentrations of selected individual substances are plotted in logarithmic scale versus layer number, i.e. the depth of sampling. Graphs contain the most important substances in relation to human health classified by Monographs on the Evaluation of Carcinogenic Risks to Humans by the International Agency for the Research of Cancer (IARC, 2010) as carcinogenic to humans (Benzo[a]pyrene), probably carcinogenic to humans (Dibenz[a,h]anthracene, Cyclopenta[c,d]parene) and possibly carcinogenic to humans (Benz[a]anthracene, Benzo[b]fluoranthene, Benzo[k]fluoranthene, Chrysene).

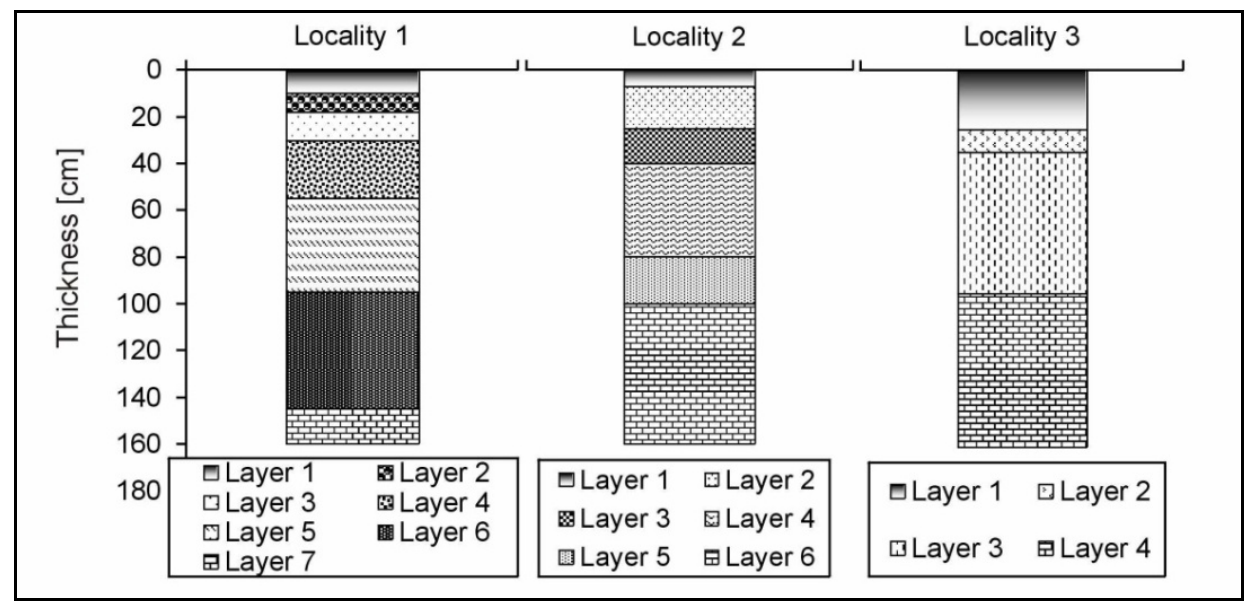

Figure 1: Cross sections of roads at particular localities. 
The highest concentrations of PAHs at localities with an older pavement surface from the nineteen fifties (locality 1) or nineteen sixties (locality 2) were found in the layer below the asphalt pavement surface. At locality 1, the total concentration of PAHs in this layer was $195.9 \mathrm{mg} \cdot \mathrm{kg}^{-1}$, which may already pose a significant pollution risk to the environment, especially because of high concentrations of benzo(a)pyrene $\left(57.6 \mathrm{mg} \cdot \mathrm{kg}^{-}\right.$ ${ }^{1}$ ), benzo(k)fluorantene (37.2 mg. $\left.\mathrm{kg}^{-1}\right)$, benzo(a)antracene $\left(22.7 \mathrm{mg} \cdot \mathrm{kg}^{-1}\right)$ and indeno(1,2,3cd)pyrene (22.1 mg.kg $\left.{ }^{-1}\right)$. This may be caused by the leaching of these substances out of the asphalt pavement and their re-sorption in soil grains in the lower layer. This notion is supported by the results of analyses made on samples from individual layers at the locality with the newest road surface from the second half of the nineteen eighties (locality 3 ), where the highest concentrations of PAHs were found in the surface layer of the pavement. Because of the lower age, the leaching of PAHs from the asphalt pavement may have not taken place to such a large extent and thus that layer still represents a dominant source of these pollutants.

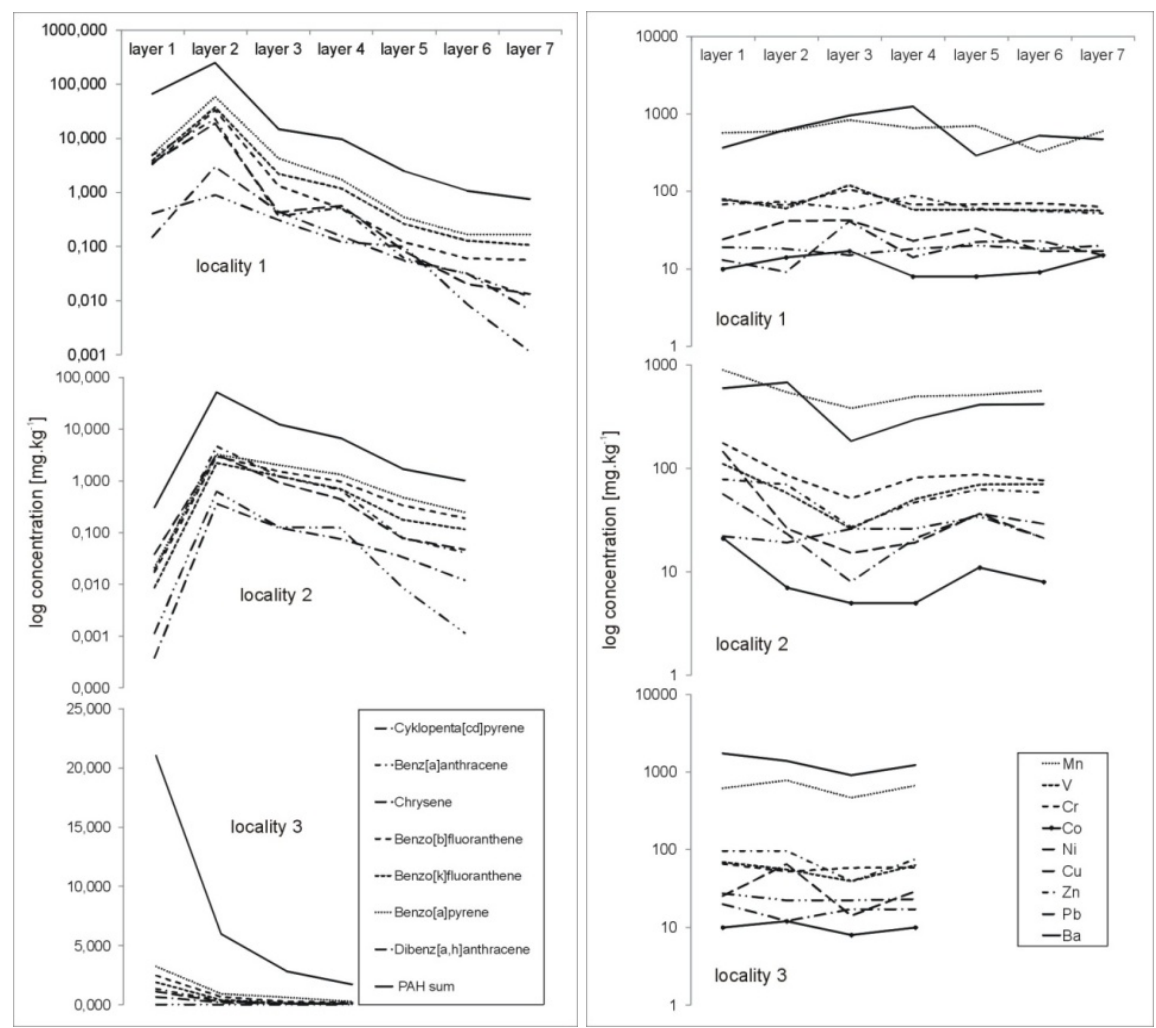

Figure 2: PAHs concentrations and selected metals concentrations in individual road layers.

Table 2: Toxicity tests results.

\begin{tabular}{ccccc}
\hline Locality & Layer & $\mathbf{p H}$ of extract & Mortality & Result \\
\hline $\mathbf{1}$ & $\mathbf{8 . 3 4}$ & $\mathbf{3 3 . 3 0} \%$ & Positive \\
2 & 7.84 & $0.00 \%$ & Negative \\
& 3 & 7.33 & $3.45 \%$ & Negative \\
Locality 1 & 7.56 & $3.22 \%$ & Negative \\
& 5 & 7.18 & $0.00 \%$ & Negative \\
& 7 & 7.24 & $0.00 \%$ & Negative \\
& 7 & 7.64 & $0.00 \%$ & Negative \\
\hline
\end{tabular}




\begin{tabular}{|c|c|c|c|c|}
\hline Locality & Layer & pH of extract & Mortality & Result \\
\hline \multirow{6}{*}{ Locality 2} & 1 & 7.13 & $10.00 \%$ & Negative \\
\hline & 2 & 7.20 & $0.00 \%$ & Negative \\
\hline & 3 & 6.89 & $3.12 \%$ & Negative \\
\hline & 4 & 6.88 & $16.12 \%$ & Positive \\
\hline & 5 & 6.65 & $0.00 \%$ & Negative \\
\hline & 6 & 6.63 & $6.45 \%$ & Negative \\
\hline \multirow{4}{*}{ Locality 3} & 1 & 6.41 & $12.90 \%$ & Positive \\
\hline & 2 & 6.60 & $3.22 \%$ & Negative \\
\hline & 3 & 6.81 & $100.00 \%$ & $\begin{array}{c}\text { Positive } \\
\left(\mathrm{LC}_{50}=\mathbf{8 0 . 6}\right)\end{array}$ \\
\hline & 4 & 6.79 & $6.45 \%$ & Negative \\
\hline
\end{tabular}

The highest PAHs concentrations in the layer subsequent to asphalt surface were also found by Sadler et al. (1999) but were lower by the order of $1-10 \mathrm{mg} \cdot \mathrm{kg}^{-1}$.

Samples from individual layers were also analyzed for the concentration of selected metals. Iron was found to be the most frequent element that was present in concentrations by two orders higher than $\mathrm{Ba}\left(182\right.$ - $\left.1733 \mathrm{mg} \cdot \mathrm{kg}^{-1}\right)$ and $\mathrm{Mn}\left(380-880 \mathrm{mg} \cdot \mathrm{kg}^{-1}\right)$ and by three orders higher than other analyzed elements. Concentrations of $\mathrm{Mo}$ and $\mathrm{Cd}$ were at all localities and in all samples below the limit of detection, which was $5 \mathrm{mg} \cdot \mathrm{kg}^{-1}$ for $\mathrm{Mo}$ and $0.8 \mathrm{mg} \cdot \mathrm{kg}^{-1}$ for Cd. These results do not indicate any dependence of the concentration of analyzed elements on depth, as is the case with PAHs. This fact is evident from the graphs in Figure 2, where concentrations of individual elements are plotted in logarithmic scale versus the depth of sampling.

The water extracts of soil samples were tested for toxicity at one trophic level. The tests were conducted using the freshwater crustacean Thamnocephalus platyurus as the indicator. The highest toxicity was found at locality 3, where the test classified two of the four layers as positive (Table 2). By testing the third layer from this locality, even $100 \%$ mortality of crustaceans was detected. This layer is formed by sandy material (grain size up to $1 \mathrm{~cm}$ ). Similar composition cannot be found in other layers. So in comparison with all the other layers, this is probably the layer with the minimum sorption capacity for toxic substances.

To assess the reason for the increased toxicity of extracts from locality 3 , concentrations of individual pollutants at all localities were compared using the statistical method ANOVA. With the exception of $\mathrm{Ba}$ and $\mathrm{Pb}$, the results of the comparison of individual localities are statistically insignificant. Concerning $\mathrm{Pb}$, only the difference between localities 1 and 2 was statistically significant. For $\mathrm{Ba}$, concentrations at locality 3 were statistically significantly higher than those at localities 1 and 2. It therefore appears that the most likely reason for the higher toxicity of extracts from locality 3 is the increased concentration of $\mathrm{Ba}$, which is most likely present in a soluble form in layer 3. Slight toxicity was detected for layer 1 at locality 1, i.e. asphalt pavement surface - with 33\% mortality of organisms - and layer 4 at locality 2 . This layer consists of gravel and a binder composed of loamy clay, and therefore re-sorption of pollutants migrating along with water from the upper layers (especially from the asphalt surface) down to the soil base might have occurred. The other layers at individual localities were classified by the test as non-toxic. The results show that the mortality of organisms was detected at all localities in the first layer - i.e. the asphalt pavement surface - and in the third or fourth layer. Although at localities 1 and 2 the highest concentrations of PAHs were detected in the second layer, the samples were classified as non-toxic, with zero mortality of the test organism. The most likely reason is the toxicity caused by heavy metals (particularly of $\mathrm{Ba}$ ), as described above. 


\subsection{Percolation water}

When sampling percolation water it is necessary to consider the time of the delay between the infiltration of water at the surface and its accumulation in the sampler. This interval cannot be precisely predicted because it depends on the water filtration rate, resistance of particular layers of the road body and on the length of filtration trajectory. The final volume of the sample is also influenced by the volume of water entering the environment. For these reasons, only two samples of percolation water were taken. We managed to eject $150 \mathrm{ml}$ (sample 1) and $920 \mathrm{ml}$ (sample 2) of groundwater from the sampler placed in the road body into the prepared glass sampling bottle. This volume was in both cases divided into three parts for the determination of organic and inorganic pollutants and for toxicity tests. In the samples the same PAHs as in soils were detected (Figure 3). The results of analyses indicate that the highest concentrations in groundwater were found for pyrene, benzo(a)pyrene and fluoranthene. With the exception of the last mentioned, these are the same compounds that were also present in the highest concentrations in road layers. Sample 2 also contained considerable concentrations of naphthalene and chrysene. However, in general, concentrations of PAHs in this sample were lower by an order of magnitude. This fact may probably be caused by the relatively quick infiltration of larger amounts of water from the surface that lasted until the spring months as the snow at this locality melted. Large quantities of infiltrating water passed through the rock environment faster and therefore there was not a prolonged contact of water with rock grains and minerals in pores. In this way a smaller amount of compounds from the surface of grains is released into the water during the contact. Determined PAHs concentrations are in accordance with Legret et al. (2005), Kriech (1990) and Kriech (1991) who found most of PAHs below the detection limit and the highest concentrations were found in all cases for fluoranthene. Detection limits were in referenced studies substantially higher than those used in this study, e.g. $0.25 \mathrm{mg} . \mathrm{l}^{-1}$ for anthracene vs. $0.005 \mathrm{mg} \cdot \mathrm{l}^{-1}$. Concentrations of metals were also determined in groundwater (Figure 4). Concentrations of alkali metals are relatively high, particularly of sodium and potassium. This may be caused particularly by the interaction of the percolation water with rubble and a binder, by which these compounds are released into the water. There is probably also a significant contribution of spreadings used for road maintenance in winter. For sample 1, the highest concentrations were determined for $\mathrm{Mo}, \mathrm{Ni}, \mathrm{Cr}$, As and $\mathrm{Be}$, and for sample 2 it was $\mathrm{Ni}$, $\mathrm{Cr}$ and additionally, also Ba. Unfortunately, determined concentrations of the selected elements differ among Legret et al. (2005) and Kriech (1991) and this study, although the pH of the leachate wasnearly the same.

Concentrations of PAHs in the $2^{\text {nd }}$ sample amounted to approximately $3 \%$ of their values obtained for sample 1. This is most probably caused by the dilution of percolation water during the spring snowmelt, which is also indicated by the detected $\mathrm{Na} / \mathrm{K}$ ratio caused probably by doping waters with sodium from winter maintenance.

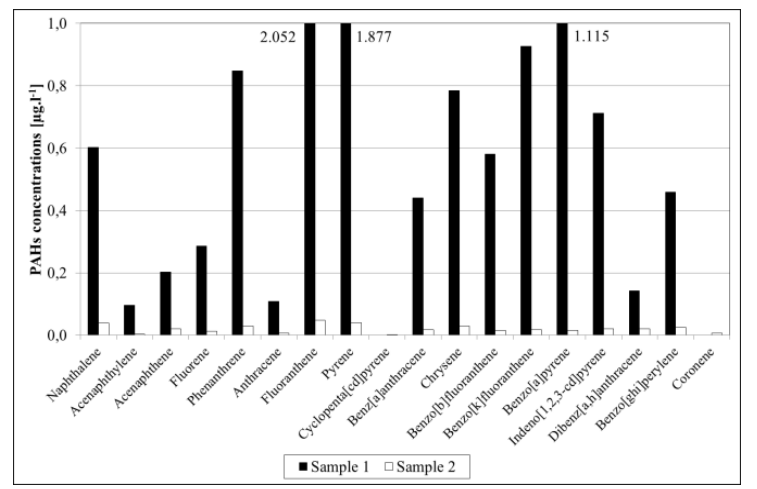

Figure 3: PAHs concentrations in percolation water samples. 


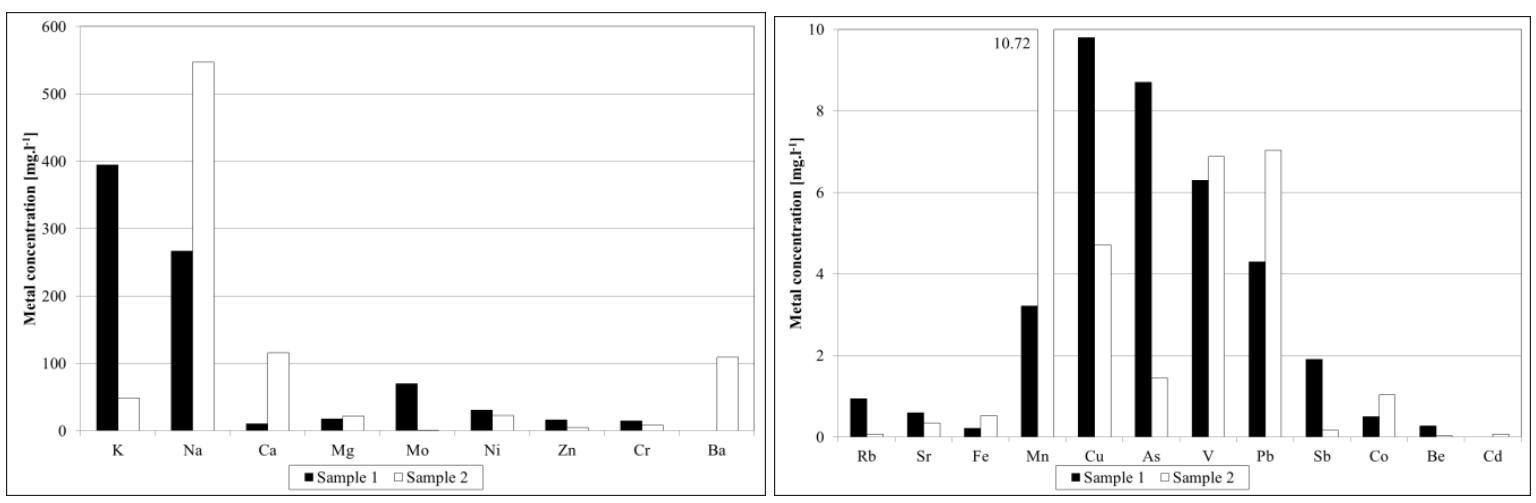

Figure 4: Metals concentrations in percolation water samples.

The samples of water were tested for toxicity using the test Thamnotox kit and the freshwater crustacean Thamnocephalus platyurus as the indicator. Both samples of groundwater can be classified as slightly toxic, as $32.2 \%$ and $36.6 \%$ mortality of organisms were detected for samples 1 and 2, respectively. Given that at comparable toxicity levels of both samples of water, concentration of PAHs in sample 2 is approximately $3 \%$ that of sample 1 , it can be almost certainly said that the toxicity of these samples is not caused by PAHs. We can speculate here about the toxicity caused by the leaching of inorganic pollutants or by combining their effects with the effect of compounds that were not analyzed.

\section{CONCLUSION}

Concentrations of PAHs determined in samples taken from individual layers of a road body decrease with increasing depth. At localities with an older pavement surface the highest concentrations of PAHs were identified in the layer underneath the asphalt pavement surface. This may be caused by the leaching of these compounds from the asphalt pavement and their resorption into soil particles in a lower layer. On the other hand, at localities with the newest road pavement the highest concentrations of PAHs were found in the surface layer of the pavement where - because of a shorter time of exposure - PAHs may not have leached out from the asphalt road pavement to such a large extent. Toxicity tests showed the negative effects on tests organisms at all localities in the first layer, i.e. the asphalt pavement surface, and in the third or fourth layer. On the other hand, samples with the highest concentrations of PAHs were classified as non-toxic. The probable reason for this is that PAHs have strongly re-adsorbed onto the surface of soil grains and that they were not released into the water extract prepared in the process of sample preparation for the test. The opposite effect may take place with metals, particularly $\mathrm{Ba}$, which probably exists in a soluble form. In samples of percolation water the same PAHs were identified as in the soils, with the highest concentrations found for pyrene, benzo(a)pyrene and fluoranthene. With the exception of fluoranthene, these are the same as those identified in highest concentrations in road construction layers. Concentrations of alkali metals, particularly of $\mathrm{Na}$ and $\mathrm{K}$, are relatively high. Their source can be seen particularly in the interactions of percolating water with rubble and a binder, or in spreadings used for road maintenance in winter. Water percolating through the road body can be classified as slightly toxic. 


\section{ACKNOWLEDGEMENT}

This work was supported by the research intention of the Ministry of Transport of the Czech Republic no. 4499457501 and the project no. 1P050C003 of the Ministry of Education, Youth and Sports of the Czech Republic.

REFERENCES

Arnold, G.K., Dawson, A. R., Miller, M., 2002. Determining the extent of ground and surface water contamination adjacent to embankments comprising pulverized fuel ash (PFA). Project report by University of Nottingham, School of Civil Engineering, Nottingham Centre for Pavement Engineering.

Berbee, R., Vermij, P., van de Laak, W. J., 2004. Policy development for the reduction of pollution caused by traffic - experiences from the Netherlands. Water Science and Technology, 49 (3), pp. 183-188.

Brandt, H. C. A., de Grooth, P. C., 2001. Aqueous leaching of polycyclic aromatic hydrocarbons from bitumen and asphalt. Water Research, 35 (17), pp. 4200-4207.

Brantley, A. S., Townsend, T. G., 1999. Leaching of pollutants from reclaimed asphalt pavement. Environmental Engineering Science, 16 (2), pp. 105-116.

ČSN EN 12457-4, 2002. Characterisation of waste - Leaching - Compliance test for leaching of granular waste materials and sludges - Part 4: One stage batch test at a liquid to solid ratio of $10 \mathrm{I} / \mathrm{kg}$ for materials with particle size below $10 \mathrm{~mm}$ (without or with size reduction). Brussels (Belgium): European Committee for Standardization.

ČSN EN 13108-1, 2008. Bituminous mixtures - Material specifications - Part 1: Asphalt Concrete. Brussels (Belgium): European Committee for Standardization.

ČSN EN 13108-5, 2008. Bituminous mixtures - Material specifications - Part 5: Stone Mastic Asphalt. Brussels (Belgium): European Committee for Standardization.

ČSN 73 6133, 2010. Road earthwork - Design and execution. Brussels (Belgium): European Committee for Standardization.

IARC, 2010. Agents Classified by the IARC Monographs. Volumes 1-102 [online]. Lyon Cedex: IARC [cited 2010-12-28]. Retrieved from: http://monographs.iarc.fr/ENG/Classification/index.php.

Hill, A. R., Dawson, A. R., Mundi, M., 2001. Utilisation of aggregate materials in road construction and bulk fill resources. Conservation \& Recycling, 32, pp. 305-320.

Krein, A., Schorer, M., 2000. Road runoff pollution by polycyclic aromatic hydrocarbons and its contribution to river sediments. Water Research, 34 (16), pp. 4110-4115.

Kriech, A. J., 1990. Evaluation of hot mix asphalt for leachability [online]. Indianapolis, Indiana (USA): Asphalt Institute. Heritage research group [cited 2008-04-15]. Retrieved from: 
http://www.asphaltinstitute.org/ai_pages/Technical_Focus_Areas/Tech_Issues_Environme ntal.asp

Kriech, A. J., 1991. Leachability of asphalt and concrete pavement [online]. Indianapolis, Indiana (USA): Asphalt Institute. Heritage research group [cited 2008-04-15]. Retrieved from:

http://www.asphaltinstitute.org/ai_pages/Technical_Focus_Areas/Tech_Issues_Environme ntal.asp

Legret, M., Colandini, V., Le Marc, C., 1996. Effects of a porous pavement with reservoir structure on the quality of runoff water and soil. Science of the Total Environment, 189/190, pp. 335-340.

Legret, M., Pagotto, C., 1999. Evaluation of pollutant loadings in the runoff waters from a major rural highway. Science of the Total Environment, 235 (1-3), pp. 143-150.

Legret, M., Odieb, L., Demarea, D., Jullien, A., 2005. Leaching of heavy metals and polycyclic aromatic hydrocarbons from reclaimed asphalt pavement. Water Research, 39 (15), pp. 3675-3685.

Leitão, T., Baekken, T., Brencic, M., Dawson, A. R., Folkeson, L., François, D., Kurimska, P., Licbinsky, R., Vojtesek, M., 2008. Contaminant sampling and analysis. In A. Dawson (ed.) Water in Road Structures: Movement, Drainage and Effects. 1st edn. Springer, Germany, pp. 147-172.

Lindgren, A., 1996. Asphalt wear and pollution transport. Science of the Total Environment, $189 / 190$, pp. $281-286$.

Pagotto, C., Legret, M., Le Cloirec, P., 2000. Comparison of the hydraulic behaviour and the quality of highway runoff water according to the type of pavement. Water Research, 34 (18), pp. 4446-4454.

Sansalone, J. J., Buchberger, S. G., 1995. An infiltration device as a best management practice for immobilizing heavy metals in urban highway runoff. Water Science and Technology, 32 (1), pp. 119-125.

SOP, Thamnotoxkit F, 1995. Standard Operational Procedure. Crustacean toxicity screening test for freshwater. Creasel, Belgium.

Sadler, R., Delamont, C., White, P., Connell, D., 1999. Contaminants in soil as a result of leaching from asphalt. Toxicologocal and Environmental Chemistry, 68 (1), pp. 71-81.

Stotz, G., Krauth, K., 1994. The pollution of effluents from pervious pavements of an experimental highway section: first results. Science of the Total Environment, 146/147, pp. 465-470.

\section{The article was produced under the support of the project} Transport R\&D Centre (CZ.1.05/2.1.00/03.0064) 